\title{
Evaluation of Alfalfa (Medicago Sativa) Cultivars at Highland and Midland of Guji Zone of Oromia
}

\author{
Teshale Jabessa $^{1,{ }^{*}, \text { Ketema Bekele }^{2}}$ \\ ${ }^{1}$ School of Animal and Range Sciences, Haramaya University, Haramaya, Ethiopia \\ ${ }^{2}$ Bore Agricultural Research Center, Bore, Ethiopia
}

Email address:

teshalejabessa@gmail.com (T. Jabessa)

${ }^{*}$ Corresponding author

\section{To cite this article:}

Teshale Jabessa, Ketema Bekele. Evaluation of Alfalfa (Medicago Sativa) Cultivars at Highland and Midland of Guji Zone of Oromia. Biochemistry and Molecular Biology. Vol. 6, No. 1, 2021, pp. 1-6. doi: 10.11648/j.bmb.20210601.11

Received: November 18, 2020; Accepted: November 30, 2020; Published: January 4, 2021

\begin{abstract}
The study was conducted with the objective to identify adaptable, high biomass yield, leaf to steam ratio and good quality yield of Alfalfa cultivars at Bore Agricultural research center. Eight Alfalfa cultivars; Hunter river, Magna-801-FG, Pioneer (1995) DZF-406, Segule1396 (408), Peruvian DZF (406), F-G-9-09, F-L-L-77-(406) and Hunter river (4010) were tested in RCBD with three replications. Plant height was significantly $(\mathrm{P}<0.05)$ higher for Hairy $(1995)$ DZF-406 cultivar $(83$ $\mathrm{cm})$ while lower for Magna-801-FG. Disease resistance was significantly differ $(\mathrm{P}<0.05)$ among cultivars. Segule (1396)-408 cultivars were highly resistant to diseases compared to others. Leaf to stem ratio, biomass yield and seed yield were not show significant $(\mathrm{P}>0.05)$ different among treatments. Chemical compositions of NDF, ADL and $\mathrm{CP}$ were significantly $(\mathrm{P}<0.05)$ different among treatments. The superior ADL was obtained from Segule (1396)-408 cultivar (32.5\%) while, low was obtained from F-L-L-77 (406) cultivar. The superior NDF was obtained from Poineer (1995) DZF-406 cultivar (70.7\%) whereas; the low was from Peruvien- DZF- 406 cultivar $(45.9 \%)$. The CP yield showed significant $(\mathrm{P}<0.05)$ difference among cultivars. Magna- 801-FG cultivar had the superior (26.3\%) CP while, Segule (1396)-408 cultivar (11.3\%) had the inferior CP content. Cultivar F-G-9-09 was produce superior in DM (91.8\%) and less in ADL (9.3\%) while Segule 1396 (1396)-408 cultivar produce (91.3\%) DM and lower in TASH (10.8\%). superior OM was obtained from Segule 1396 (408) cultivar (80.4\%) compared to others. Based on its yield, plant height, biomass yield and chemical compositions, good DM and OM PeruvienDZF- 406, F-L-L-77 (406,) Segule-1396 (408) and F-G-9-09 is recommended for further promotion in the highland and midland of Guji and similar agro-ecologies.
\end{abstract}

Keywords: Medicago, Sativa, Adola, Cultivar

\section{Introduction}

Alfalfa (Medicago sativa L.) is often recognized as one of the most important perennial forage legumes worldwide and is widely known as the "queen of the forages" due to its ability to consistently produce high forage yield and forage quality and adaptability to different climatic conditions $[1,2]$. Alfalfa is a drought tolerant forage crop because it has a deep root system that reaches down to $4 \mathrm{~m}$ and to $7-9 \mathrm{~m}$ in well drained soils. The plant survive long periods of water stress by impeding its vegetative growth [3] and accessing water from deep layers through its long root system [4]. The optimum growing air and soil temperatures for alfalfa are $27^{\circ} \mathrm{C}$ and $12^{\circ} \mathrm{C}$ respectively, but it is tolerant of air temperatures above and below $27^{\circ} \mathrm{C}[5]$.

This forage legume is also known as an effective source of biological nitrogen fixation, an energy-efficient crop to grow and an important source of protein yield. The optimum soil $\mathrm{pH}$ range for alfalfa is 6.5 to 7.5 and tolerates relative salinity. Alfalfa grows best on well-drained, deep soils but it thrives on sandy soils with adequate moisture and fertility [6]. Alfalfa does not grow well on soils where root growth is limited such as shallow hardpans, high water tables, bedrock or acidic sub soils [7].

Poorly drained or waterlogged soils are strongly discouraged for alfalfa because root and crown diseases reduce stand longevity under these conditions. The crop needs very frequent irrigation during its early growth period 
at an interval of about one week but once the plants are established, subsequent irrigations are provided at an interval of 10-15 days during dry season. Alfalfa is one of the few cultivated forage crops that can produce high level of biomass with minimum inputs. Low quality crop residues need nitrogen supplementation, often provided by forage legumes to become productive diets [8].

Climate, cultivation practices, feed technologies and genetic variations are the main factors affecting the nutritional value of feed for livestock. Forage legumes contribute significantly to livestock production in crop livestock systems. Legume forages generally lead to higher intakes and animal production than grass silages of comparable digestibility [9]. Alfalfa nutritive value is identified with protein content which depends on the share of leaves in dry matter yield which in turn is positively correlated with protein content. The proportion of leaves and stems in alfalfa hay can vary greatly, depending on maturity at harvest, cultivars, handling and rain damage [10]. Protein content in alfalfa dry matter varies from 18 to $25 \%$ depending on the growth stage, cultivar difference and other factors. Alfalfa is one of the most important forage legumes of the world as major source of protein for livestock and it is a basic component in rations for all classes of domestic animals [11].

Where alfalfa can easily be grown, it is regarded as key forage for high-producing ruminants because of its richness in protein, palatability, high calcium and vitamin content. In many cases animals feeding on alfalfa do not require supplements. [12] noted that because of its very high feed value, alfalfa should be used as a supplement for crop residues and natural hay in mixture of 30 percent alfalfa and 70 percent other roughages. Alfalfa produces more protein per hectare than other legume and grasses; therefore, it is widely used for hay production and as pasture for livestock, especially to ruminants [13]. Ruminants fed on alfalfa have higher nutrient intake and digestibility than when fed on other forage legumes and grasses [14]. To improve availability of livestock feed in terms of quantity and quality, it is better to cultivate alfalfa forage that have better biomass yield and nutritional quality. Therefore, the objective of the present study was to evaluate the adaptability potential Good biomass yield, leaf to steam ratio and nutritional quality of alfalfa cultivars grown at high land and mid land parts of Guji zone.

\section{Materials and Methods}

\subsection{Description of the Study Area}

The experiment was carried out at Songo baricha on station and Adola sub-site of Bore Agricultural Research Center. Bore district is located at $385 \mathrm{~km}$ to the south of Oromia from Finfinne and $220 \mathrm{~km}$ from the Guji Zone capital city (Negele) with geographical location of 557'23" to 626'52" N latitudes and 3825'51" to 3856'21" E longitudes, South-eastern Oromia. The annual rain fall is about 1400$1800 \mathrm{~mm}$ and the annual temperatures of the district ranged from 10.1 to $20^{\circ} \mathrm{C}$. The major soil types of the site are mostly black soil. Bore Agricultural Research station is located at 7 $\mathrm{km}$ from Bore district which is geographically located at 624'37" N latitude and 3834'76" E longitudes. The research station represents highlands of Guji Zone with an altitude of 2736 m. a. s. 1. receiving high rainfall characterized by bimodal distribution. The first rainy season extends from April to October and the second season starts late November and ends at the beginning of March. Adola district is located at distance of $470 \mathrm{~km}$ from Addis Ababa and $120 \mathrm{~km}$ from the Zonal capital city, Negele Borena. The areas are a mixed farming and semi-nomadic economic activity takes place, which is the major livelihood of the local peoples. The District is situated at $5^{\circ} 44^{\prime} 10^{\prime \prime}-6^{\circ} 12^{\prime} 38 \mathrm{~N}$ and $38^{\circ} 45^{\prime} 10^{\prime \prime}-3^{\circ} 12^{\prime} 37^{\prime \prime} \mathrm{E}$. The District is characterized by highland (11\%), midland $(29 \%)$ and lowland $(60 \%)$. The major soil types of the district are nitosols (red basaltic soils) and orthic acrosols [15].

\subsection{Experimental Treatments and Design}

The experiment was conducted using eight Alfalfa cultivars Hunter river, Magna-801-FG, Pioneer (1995) DZF406, Segule1396 (408), Peruvian DZF (406), F-G-9-09, F-LL-77-406 and Hunter river (4010). The experiment was conducted in randomized complete block design (RCBD) with three replications. Seeds were sown in rows spaced 20 $\mathrm{cm}$ and $1 \mathrm{~m}, 1.5 \mathrm{~m}$ between plot and block respectively on plot size of $2 \mathrm{~m} \times 2 \mathrm{~m}\left(4 \mathrm{~m}^{2}\right)$. Seed \& fertilizer was applied and other agronomic crop protection practices were adopted uniformly as per recommendation for production.

\subsection{Methods of Data Collections}

All relevant data like plant height, Biomass yield, seed yield, leaf to stem ratio and resistance to disease and insect were carefully recorded.

\subsection{Chemical Analysis}

For forage quality analysis, chopped herbage of the three replications were pooled into one and properly homogenized and one representative subsample was taken for each cultivar. The DM and ash contents were determined by oven drying at $105^{\circ} \mathrm{C}$ overnight and by igniting in a muffle furnace at $500^{\circ} \mathrm{C}$ for 6 hours, respectively. Nitrogen (N) content was determined by Kjeldahl method and $\mathrm{CP}$ was calculated as $\mathrm{N}$ x 6.25 [16]. The neutral detergent fiber (NDF), acid detergent fiber (ADF) and acid detergent lignin (ADL) fractions were analyzed according to [17].

\subsection{Statistical Analysis}

All collected data were analyzed using general linear model procedure SAS [18]. version 9.1. Means were separated with least significant difference (LSD) at 5\% significant level. The statistical model for the analysis data was: $Y_{i j k}=\mu+A_{j}+B_{i}+e_{i j k}$

Where; $Y_{\mathrm{ijk}}=$ response of variable under examination, $\mu=$ overall mean, $A_{j}=$ the $j$ th factor effect of treatment, $B_{i}=$ the ith factor effect of block/ replication, $\mathrm{e}_{\mathrm{ijk}}=$ the random error. 


\section{Results and Discussions}

\subsection{Yield and Yield Related Components}

The experiment was conducted on eight improved Alfalfa cultivars to select the highes yield and best performing in all agronomic traits and good quality compositions. Combined mean values of agronomic characters, mean values of agronomic traits and yield components of Alfalfa cultivars on different locations and combine mean values of chemical compositions are presented in Table 1, Table 2 and Table 3 respectively.

Plant Height at Forage Harvesting Stage

For plant height determination, mean height of five randomly selected plants were recorded for each plots of the trial. Plant height was significantly differ $(\mathrm{P}<0.05)$ among cultivars at forage harvesting stages Table 1. Plant height was significantly higher for Hairy (1995) DZF-406 cultivar (83 $\mathrm{cm})$ and medium for $F-L-L-77$ (406) cultivar $(82.9 \mathrm{~cm})$ whereas lower for Magna-801-FG cultivar $(63.8 \mathrm{~cm})$. The result of this study agreed with that of [19] where they reported significant variation for Alfalfa cultivars.

Disease Resistance

Disease resistance was significantly differ $(\mathrm{P}<0.05)$ among cultivars at different growth stages of the forages Table 1. From eight Alfalfa adapted at Bore Agricultural research center, four cultivars Hunter River (4010), Poineer (1995) DZF-406, Hunter River and F-L-L-77 (406) were highly attacked by diseases while Magna- 801-FG, PeruvienDZF- 406, F-G-9-09 and Segule (1396)-408 cultivars were resistant to diseases compared to the other cultivars observed in the study areas over two consecutive years.

Mean Fractions of Leaf to Steam Ratio
Leaf to stem ratio was determined by separately harvesting a central section of two adjacent middle rows with a sampling area of $0.25 \mathrm{~m}^{2}(0.5 \mathrm{~m}$ length $\mathrm{x} 0.5 \mathrm{~m}$ width $)$ and by partitioning the harvested biomass in to leaf and stem fractions. Leaf to stem ratio was not significantly different $(\mathrm{P}>0.05)$ among alfalfa cultivars at forage harvesting stage. Leaf to stem ratio was superior for Hunter river-4010 cultivar (0.71) followed by Peruvien- DZF-406 cultivar (0.69) and the lower was obtained from Poineer (1995) DZF-406 cultivar (0.54). This is agreed with the results of [20, 21]. The non-significant cultivars differences in leaf to stem ratio at forage harvesting stage observed in the present study is dis-agreement with other reports [22-24, 21], but happens at the same time with others research findings $[25,19,26]$.

Mean Biomass yield of Cultivars

Fresh weight of the cut biomass was recorded just after mowing using field balance. Then, sub-samples of $300 \mathrm{~g}$ was taken and dried in air draft oven at $65^{\circ} \mathrm{C}$ for 72 hours to determine herbage dry matter yield (DMY). The combined mean biomass yield were not show significant $(\mathrm{P}>0.05)$ different among treatments. The highest mean value of biomass yield was obtained from Segule-1396-(408) cultivar (8.2 t/ha) followed by $F-L-L-77$ (406) cultivar (8.07 t/ha). The lowest biomass yield was obtained from Hunter river (4010) cultivar (7.13 t/ha).

\section{Combined Mean Seed Yield}

Combined mean seed yield were not show significant $(\mathrm{P}>0.05)$ different among treatments. The superior seed yield was obtained from Segule-1396 (408) cultivar (0.083 qt/ha) and the lower seed yield was obtained from Hunter river (4010), Hunter river, F-L-L-77 (406) and Magna- 801-FG cultivars respectively.

Table 1. Combined mean values of different agronomic traits and yield related components of Alfalfa cultivars from two locations Adola sub-site and songo on station.

\begin{tabular}{llllll}
\hline Cultivars & PH (cm) & Ds & LSR & SY q $^{-1}$ & fBMYt $^{-1}$ \\
\hline F-L-L-77 (406) & $82.9^{\mathrm{a}}$ & $1.42^{\mathrm{abc}}$ & 0.63 & 0.08 & 8.07 \\
Magna- 801-FG & $63.8^{\mathrm{b}}$ & $1 \mathrm{a}^{\mathrm{bc}}$ & 0.62 & 0.07 & 7.31 \\
Peruvien- DZF- 406 & $83^{\mathrm{a}}$ & $0.7^{\mathrm{abc}}$ & 0.69 & 0.08 & 7.90 \\
F-G-9-09 & $71 \mathrm{a}^{\mathrm{b}}$ & $0.67^{\mathrm{bc}}$ & 0.62 & 0.07 & 7.68 \\
Poineer (1995) DZF-406 & $82.4^{\mathrm{a}}$ & $1.75^{\mathrm{ab}}$ & 0.54 & 0.08 & 8.05 \\
Segule (1396)-408 & $79.8^{\mathrm{a}}$ & $0 \mathrm{c}$ & 0.66 & 0.083 & 8.2 \\
Hanter River (4010) & $79.6^{\mathrm{a}}$ & $2.17^{\mathrm{a}}$ & 0.7 & 0.07 & 7.13 \\
Hanter River & $73^{\mathrm{ab}}$ & $1.42^{\mathrm{abc}}$ & 0.56 & 0.07 & 7.32 \\
Mean & 77.1 & 1.15 & 0.62 & 0.076 & 7.71 \\
CV & 17.1 & 140 & 33.2 & 21.18 & 28.9 \\
LSD (5\%) & $*$ & $*$ & $\mathrm{NS}$ & $\mathrm{NS}$ & $\mathrm{NS}$ \\
\hline
\end{tabular}

${ }^{\text {a,b,c }}$ Mean in a column within the same category having different superscripts differ significantly $(\mathrm{p}<0.05) \mathrm{PH}(\mathrm{cm})=$ plant height in centimeter, Ds $=$ Disease resistance, $\mathrm{LSR}=$ leaf to steam ratio, $\mathrm{SYqt}^{-1}=$ seed yield cuntal per hectare, $\mathrm{fBMYt}^{-1}=$ fresh biomass yield tone per hectare, $\mathrm{CV}=\mathrm{Coefficient}$ of variation, $\mathrm{LSD}=$ Least significant difference, ${ }^{*}=$ significantly different, $\mathrm{NS}=$ None significant different.

Yield and yield Related of Alfalfa Cultivars from Different Locations

Mean value of agronomic and yield parameters of alfalfa cultivars are show in Table 2 . The analyzed result show that plant height and disease were significantly $(\mathrm{P}<0.05)$ different among treatments. Alfalfa cultivars were more attacked by diseases at Songo on station than at Adola sub-site. Highly attacked cultivar by diseases was Hunter river cultivar (2.5) at Songo on station where as, Magna-801-FG cultivar (2) were highly diseased at Adola sub-site. Segule-1396 (408) cultivar was resistant to disease at both locations and Magna801-FG cultivar at Songo on station. The rest cultivars were comparable with each others at both locations.

The long plant height was measured from F-L-L-77 (406) 
cultivar $(99.22 \mathrm{~cm})$ at Adola sub-site whereas; Segule-1396 (408) cultivar $(76.05 \mathrm{~cm})$ was the long plant height at Songo on station. On the other hand the short plant height was obtained from Magna $-801-F G(69.5 \mathrm{~cm})$ cultivar at Adola sub-site and Hunter River (4010) cultivar (49 cm) at Songo on station compared to the other cultivars.

Leaf to steam ratio, Biomass yield and seed yield were not show significant $(\mathrm{P}>0.05)$ different among treatments.

Table 2. Mean value of agronomic traits and yield components of Alfalfa cultivars on different locations.

\begin{tabular}{|c|c|c|c|c|c|c|c|c|c|c|}
\hline \multirow{3}{*}{ Cultivars } & \multicolumn{10}{|c|}{ Locations } \\
\hline & \multicolumn{5}{|c|}{ Adola sub-site } & \multicolumn{5}{|c|}{ Songo staion } \\
\hline & PH cm & DS & LSR & SY qt ${ }^{-1}$ & BMYt $^{-1}$ & PH cm & D企 & LSR & SY qt ${ }^{-1}$ & fBMYt $^{-1}$ \\
\hline$F-L-L-77$ (406) & $99.2 \mathrm{a}$ & $0.8 \mathrm{ab}$ & 0.63 & 0.06 & 8 & $63.12 \mathrm{ab}$ & $2 \mathrm{ab}$ & 0.62 & 0.105 & 8.0 \\
\hline Magna- 801-FG & $69.5 \mathrm{c}$ & $2 \mathrm{a}$ & 0.61 & 0.05 & 7 & $63 \mathrm{ab}$ & $0 \mathrm{c}$ & 0.61 & 0.08 & 7.6 \\
\hline Peruvien-DZF- 406 & $97.6 \mathrm{ab}$ & $1 \mathrm{ab}$ & 0.72 & 0.07 & 8 & $66.75 \mathrm{ab}$ & $0.5 \mathrm{bc}$ & 0.66 & 0.09 & 7.8 \\
\hline$F-G-9-09$ & $82.8 \mathrm{bc}$ & $0.5 \mathrm{ab}$ & 0.58 & 0.06 & 7.25 & $61 \mathrm{ab}$ & $0.8 \mathrm{abc}$ & 0.64 & 0.08 & 8.1 \\
\hline Segule (1396)-408 & $88.6 \mathrm{ab}$ & $0 \mathrm{~b}$ & 0.69 & 0.08 & 8 & $76.05 \mathrm{a}$ & $0 \mathrm{c}$ & 0.61 & 0.08 & 8.1 \\
\hline Hanter River (4010) & $93.8 \mathrm{ab}$ & $2 \mathrm{a}$ & 0.69 & 0.06 & 7.2 & $49 b$ & $2.3 \mathrm{ab}$ & 0.72 & 0.08 & 7.05 \\
\hline Hanter River & $88.6 \mathrm{ab}$ & $0.3 \mathrm{ab}$ & 0.56 & 0.05 & 7.2 & 66.66 & $2.5 \mathrm{a}$ & 0.57 & 0.09 & 7.4 \\
\hline Mean & 89.7 & 1.02 & 0.63 & 0.06 & 7.6 & 64.2 & 1.27 & 0.62 & 0.09 & 7.78 \\
\hline $\mathrm{CV}$ & 8.6 & 156 & 31.1 & 26 & 22.5 & 15.9 & 128 & 27.6 & 17.8 & 20.5 \\
\hline $\operatorname{LSD}(5 \%)$ & $*$ & $*$ & NS & NS & NS & $*$ & $*$ & NS & NS & NS \\
\hline
\end{tabular}

${ }^{a, b, c}$ Mean in a column within the same category having different superscripts differ significantly $(\mathrm{p}<0.05) \mathrm{PH}(\mathrm{cm})=\mathrm{plant}$ height in centimeter, D $=\mathrm{Disease}$ resistance, $\mathrm{LSR}=$ leaf to steam ratio, $\mathrm{SYqt}{ }^{-1}=$ seed yield cuntal per hectare, $\mathrm{fBMYt}^{-1}=$ fresh biomass yield tone per hectare, $\mathrm{CV}=\mathrm{Coefficient}$ of variation, $\mathrm{LSD}=$ Least significant difference, ${ }^{*}=$ significantly different, NS= None significant different.

\subsection{Chemical Composition}

From tested alfalfa cultivars, all the traits showed nonsignificant $(\mathrm{P}>0.05)$ difference except $\mathrm{NDF}$, ADL and $\mathrm{CP}$ Table 3. Alfalfa F-G-9-09 cultivar was produce superior in DM (91.8\%) and less in ADL (9.3\%) while Segule 1396 (1396) 408 cultivar produce $(91.3 \%)$ DM and lower in TASH $(10.8 \%)$. The higher result of current study was $(91.8 \%)$ dry matter percentage which was higher than the result reported. The highest OM was obtained from Segule 1396 (408) (80.4\%) cultivar, flowed by F-G-9-09 $(80.1 \%)$ cultivar. The superior ADL was obtained from Segule (1396)-408 cultivar (32.5\%), followed by Hunter River Poineer (1995) DZF-406 cultivar (20.5\%) whereas the last was obtained from $F-L-L-77$ (406) cultivar. The ADL content showed variability $(\mathrm{P}<0.05)$ difference among the tested alfalfa cultivars, this is dis-agreed with result reported by $[19,21]$.
The superior NDF was obtained from Poineer (1995) DZF-406 cultivar (70.7\%), followed by Hanter River cultivar $(64.8 \%)$ where as the least was from Peruvien- DZF- 406 cultivar (45.9\%). This result is agreement with the result reported by [19] NDF contents of alfalfa cultivars but, disagreement to the result [21] reported non-significant differences for NDF contents of alfalfa cultivars. The current results revealed that the highest NDF contents recorded for Poineer (1995) DZF-406, indicating low quality alfalfa cultivar when compared with others [19].

The CP yield showed significant $(\mathrm{P}<0.05)$ difference among the tested cultivars. The result revealed that Magna$801-F G$ cultivar had the highest $(26.3 \%) \mathrm{CP}$ followed by Hanter River (4010) cultivar (24.6\%) while Segule (1396)408 cultivar (11.3\%) had the lowest CP content. This result is des- agreed with the result reported by [19] for the same cultivar evaluated under supplementary irrigation.

Table 3. Combined mean chemical composition of alfalfa cultivar from Adola sub-site and Songo on station.

\begin{tabular}{|c|c|c|c|c|c|c|c|}
\hline Cultivars & DM & TASH & OM & NDF & ADF & ADL & $\mathbf{C P}$ \\
\hline F-L-L-77 (406) & 89.4 & 13.7 & 75.7 & $46.3^{c}$ & 43.5 & $11.6^{\mathrm{b}}$ & $22.9^{\mathrm{ab}}$ \\
\hline Magna- 801-FG & 90.8 & 12.5 & 78.3 & $57^{\mathrm{abc}}$ & 43.75 & $21.6^{\mathrm{ab}}$ & $26.3^{\mathrm{a}}$ \\
\hline Peruvien- DZF- 406 & 88.17 & 13.3 & 74.79 & $45.9^{\mathrm{c}}$ & 40.7 & $9.47^{\mathrm{b}}$ & $17.4^{\mathrm{bc}}$ \\
\hline F-G-9-09 & 91.8 & 11.6 & 80.1 & $55.1^{\mathrm{bc}}$ & 37.6 & $9.3^{\mathrm{b}}$ & $22.5^{\mathrm{ab}}$ \\
\hline Poineer (1995) DZF-406 & 90.7 & 12.4 & 78.34 & $70.7^{\mathrm{a}}$ & 40.9 & $20.3^{\mathrm{ab}}$ & $22.2^{\mathrm{a}}$ \\
\hline Segule (1396)-408 & 91.3 & 10.8 & 80.4 & $58 \mathrm{a}^{\mathrm{bc}}$ & 40.8 & $32.5^{\mathrm{a}}$ & $11.3^{\mathrm{c}}$ \\
\hline Hanter River & 90.3 & 12.3 & 78 & $64.8^{\mathrm{ab}}$ & 44.7 & $15.8^{\mathrm{b}}$ & $23.4^{\mathrm{ab}}$ \\
\hline Mean & 90.28 & 12.46 & 77.8 & 57 & 41.2 & 16.7 & 21.3 \\
\hline $\mathrm{CV}$ & 2 & 14.79 & 3.8 & 9.5 & 13.1 & 31.3 & 15.6 \\
\hline $\operatorname{LSD}(5 \%)$ & NS & NS & NS & $*$ & NS & $*$ & $*$ \\
\hline
\end{tabular}

a,b,c Mean in a column within the same category having different superscripts differ significantly $(\mathrm{p}<0.05) \mathrm{DM}=\mathrm{dry}$ matter, TASH=total ash, OM=organic matter, $\mathrm{NDF}=$ neutral detergent fiber, $\mathrm{ADF}=$ acid detergent fiber, $\mathrm{ADL}=$ acid detergent lignin, $\mathrm{CP}=\mathrm{crude}$ protein, $\mathrm{CV}=\mathrm{Coefficient}$ of variation, $\mathrm{LSD}=\mathrm{Least}$ significant difference, ${ }^{*}=$ significantly different, $\mathrm{NS}=$ None significant different. 


\section{Conclusions and Recommendations}

The result implies that Peruvien- DZF- 406, F-L-L-77 (406), Segule-1396 (408) and F-G-9-09 cultivars were well adapted and being productive regarding the plant height, biomass yield and leaf to steam ratio which, is hopeful to fill the gap of low quality and quantity ruminant feed supply of the community. The current study indicated that Segule-1396 (408) cultivar was resistant to disease at both study area. Regarding the nutritional values (chemical composition) were promising particularly the dry matter (DM) and Organic Matter (OM) content in Peruvien- DZF406, F-L-L-77 (406), Segule-1396 (408) and F-G-9-09. Thus, it could be possible to conclude that Alfalfa cultivars especially Segule-1396 (408) and F-G-9-09 used as a protein supplement for highland and midland of Guji, which were suffering from poor quality roughage and low protein and digestible crop residues which were the major livestock feed sources particularly in Guji. Based on its adaptability, plant height, biomass yield and chemical compositions, good DM and OM Peruvien- DZF- 406, F-L-L-77 (406,) Segule-1396 (408) and F-G-9-09 is recommended for further promotion in the highland and midland of Guji and similar agro-ecologies.

\section{Acknowledgements}

The authors are grateful to the Oromia Agricultural Research Institute (IQQO) for financial support to implement the study. The animal nutrition laboratory workers of Haramaya University and Debre zeyit agricultural research center were also acknowledged for their support in the chemical analysis of the feed samples.

\section{References}

[1] Kamalak, A.; Canbolat, O.; Gurbuz, Y.; Ozay, O., 2005. In situ ruminal dry matter and crude protein degradability of plant- and animal-derived protein sources in Southern Turkey. Small Rumin. Res., 58 (2): 135-141.

[2] Turan M., Kiziloglu F M. \& Ketterings Q M. (2009). Phosphorus management of lucerne grown on calcareous soil in Turkey. J. Plant Nutr., 32, 516-535.

[3] Annicchiarico P, L Pecetti, A Abdelguerfi, Bouizgaren A, Carroni AM, Hayek T, M'Hammadi BM, Mezni M, 2010. Adaptation of landrace and variety germplasma and selection strategies for lucerne in the Mediterranean basin. Field Crops Res 120: 283-291.

[4] Volaire F. (2008). Plant traits and functional types to characterize drought survival of pluri specific perennial herbaceous swards in Mediterranean areas. Eur. J. Agron., 29: $116-124$.

[5] McKenzie, J. S., R. Paquin, and S. H. Duke. (1988). Cold and heat tolerance. p. 259-302. In A. A. Hanson et al. (ed.) Alfalfa and alfalfa improvement. Agron. Monogr. 29. ASA, CSSA, and SSSA, Madison, WI.
[6] Barnhart, S. K. (1997). Establishing alfalfa for grazing system. p. 21-24. In Proc. 2nd National Alfalfa Grazing Conf., Omaha, NE. 16 Aug. 1997. Certified Alfalfa Seed Council, Inc., Woodland, CA.

[7] Lacefield, G., D. Ball, T. Johnson, and H. White. (1987). Alfalfa in the South. Spec. Publ. Certified Alfalfa Seed Council, Inc., Woodland, CA.

[8] Anderson, F. M. (1985). Draught animal power systems in Sub-Saharan Africa. TheirAnnicchiarico P., Pecetti L., Abdelguerfi A., Bouizgaren A., Carroni A. M., Hayek T.

[9] Dewhurst R. J., Fisher W. J., Tweed J. K. S. and Wilkins R. J. (2003). Comparison of grass

[10] Katić S., Mihailović V., Milić D., Karagić Đ., Vasiljević S. (2006). Variation of crude protein content in alfalfa due to genotype and environment. Proceedings of the 2nd COST 852 Workshop Sward Dynamics, N-flows and Forage Utilisation in Legume-Based Systems, Grado, Italy, 10-12 November 2005, 251-255.

[11] Barnes D. K., Goplen B. P. and Baylor J. E. (1988). Highlights in the USA and Canada. p124. In content in alfalfa due to genotype and environment. Proceedings of the 2nd COST 852

[12] Alemayehu Mengistu. (2002). Forage production in Ethiopia: A case study with implications for alfalfa cultivars (M. sativa L.) in Jiraft, Iran. Plant Ecology 3: 109-118

[13] Monteros J. M., Bouton H. J. (2009). The future of alfalfa and forage crops. Proceedings of the of variety on chemical composition, in vitro gas production, metabolizable energy and organic productivity impact and research needs. Proceedings of International workshop held at James Cook University, Tomensville, Qld, Australia. ACIAR. pp. 26-31.

[14] Frame J. (2005). Medicago sativa L. grassland index. A searchable catalogue of grass and forage legumes.

[15] Yazachew E, Kasahun D (2011). The National regional government of Oromia, Physical and socio economic profile of Guji zone districts. Bureau of Finance and Economic Development. The National Regional Government of Oromia, Addis Abeba.

[16] AOAC. (1995). Official Methods of Analysis. 16th ed. Association of Official Analytical Chemists, Arlington, VA.

[17] Van Soest PJ, Robertson JB (1985). Analysis of Forages and Fibrous Foods. A Laboratory manual for Animal Science 613. Cornel University, Ithaca. New York, USA, P. 202.

[18] Statistical Analysis System (SAS). 2002. SAS/STAT guide for personal computers, version 9.0Strategies for lucerne in the Mediterranean basin. Field Crops Research, 120: 283-291. The national Regional Government of Oromia, Addis Abeba Turkey. J. Plant Nutr. 32, 516-535.

[19] Diriba G, Mekonnen H, Ashenafi M, Adugna T. (2014). Biomass yield potential and nutritive value of selected Alfalfa (Medicago sativa). Cultivars grown under tepid to cool submoist agro-ecology of Ethiopia. E3 Journal of Agricultural Research and Development Vol. 4 (1). Pp. 007-014, January, 2014. 
[20] Solomon W, Tesfay A, (2014). Evaluation of dry matter yield, yield components and nutritive value of selected alfalfa (Medicago sativa L.) cultivars grown under Lowland Raya Valley, Northern Ethiopia. Vol. 14 (15), pp. 705-711.

[21] Mekuanint G., Ashenafi M. and Diriba G. (2015). Biomass yield dynamics and nutritional quality of alfalfa (Medicago sativa L.) cultivars at Debre Zeit, Ethiopia. E3 Journal of Agricultural Research and Development Vol. 5 (2). Pp. 01200127, June, 2015 Monirifar H. (2011). Path analysis of yield and quality traits in Alfalfa. Not Bot Horti Agrobo 39: 190195.

[22] Lamb JFS, Sheaffer CC, Samac DA. (2003). Population density and harvest maturity effects on leaf and stem yield in alfalfa. Agronomy Journal 95: 635-641 legume silages for milk production. Production responses with different levels of concentrate livestock production. pp 1-111. Ethiopia. Soc. of Anim. Prod. Addis Ababa, Ethiopia.

[23] Hayek T, Loumerem M, Nagaz K, Thabet M. (2008). Growth development and dry matter yield of 16 Lucerne genotypes cultivated in South Tunisia. In: Porqueddu C. and Tavares de Sousa M. M. (eds.). Sustainable Mediterranean Grasslands and their multifunctions. Zaragoza: CIHEAM/FAO/ENMP/SPPF, 2008. P. 299-302 (Options Mediterraneennes: Serie A. Seminaires Mediterraneens; n. 79) Italy, 10-12 November 2005, 251-255. Jour. Dair. Sci., 86, 2598-2611.

[24] Monirifar H. (2011). Path analysis of yield and quality traits in Alfalfa. Not Bot Horti Agrobo 39: 190-195.

[25] Afsharmanesh G. (2009). Study of some morphological traits and selection of drought resistant alfalfa cultivars (M. sativa L.) in Jiraft, Iran. Plant Ecology 3: 109-118.

[26] Gashaw M, Mengistu A, Gelti D (2015). Biomass yield dynamics and nutritional quality of alfalfa (Medicago sativa) cultivars at Debre Zeit, Ethiopia. Journal of Agricultural Research and Development 5: 120-127. 